\title{
Cullin 7 in tumor development: a novel potential anti-cancer target
}

\author{
Yumiao LI ${ }^{1, *}$, Aiming ZANG ${ }^{1, *}$, Jiejun $\mathrm{FU}^{2}$, Youchao JIA ${ }^{1, *}$ \\ ${ }^{1}$ Department of Medical Oncology, Affiliated Hospital of Hebei University, Hebei Key Laboratory of Cancer Radiotherapy and Chemotherapy, \\ Baoding, Hebei, China; ${ }^{2}$ Department of Cell Biology and Genetics, Guangxi Medical University, Key Laboratory of Longevity and Aging-related \\ Diseases of Chinese Ministry of Education, Center for Translational Medicine and School of Preclinical Medicine, Nanning, Guangxi, China
}

${ }^{*}$ Correspondence: youchaojia20@163.com

${ }^{*}$ Contributed equally to this work.

Received December 7, 2020 / Accepted January 25, 2021

\begin{abstract}
As a core scaffold protein, Cullin 7 (Cul7) forms Skp1-Cullin-F-box (SCF) E3 ubiquitin ligase complexes with the regulator of cullins-1 (ROC1), S-phase kinase associated protein 1 (Skp1) and F-Box, and WD repeat domain containing 8 (Fbxw8). Alternatively, Cul7 can form a CRL7SMU1 complex with suppressor of Mec-8 and Unc-52 protein homolog (SMU1), damage-specific DNA binding protein 1 (DDB1), and ring finger protein 40 (RNF40), to promote cell growth. The mutations of Cul7 cause the 3-M dwarf syndrome, indicating Cul7 plays an important role in growth and development in humans and mice. Moreover, Cul7 regulates cell transformation, tumor protein p53 activity, cell senescence, and apoptosis, mutations in Cul7 are also involved in the development of tumors, indicating the characteristics of an oncogene. Cul7 is highly expressed in breast cancer, lung cancer, hepatocellular carcinoma, pancreatic cancer, ovarian cancer, and other malignant tumors where Cul7 promotes tumor development, cell transformation, and cell survival by regulating complex signaling pathways associated with protein degradation. In this review, we discuss the roles of Cul7 in malignant tumor development and its involvement in oncogenic signaling. We finally discuss the potential of Cul7 as a potential significant anti-cancer target.
\end{abstract}

Key words: Cullin 7, tumor, ubiquitin ligase, p53, apoptosis

Cullin 7 (Cul7), formerly known as KIAA0076, initially cloned from the cDNA library of human immature myeloid cell line $\mathrm{KG}-1$, is a member of the Cullin protein family including Cul1, Cul2, Cul3, Cul4A, Cul4B, Cul5, Cul7, and Cul9 (parkin-like cytoplasmic protein, PARC) [1-5], which contains a region homologous and a more $\mathrm{C}$-terminal region homologous to Cullins [6-9]. As a DOC domain-containing cullin, Cul7 is involved in assembling an SCF-ROC1-like E3 ubiquitin ligase complex including Skp1, Cul7, Fbx29, and ROC1 [6]. The coding region of Cul7 is located on the short arm of human chromosome 6 (6p21.1) [10]. Cul7 contains 1698 amino acids in length and is expressed in almost all human tissues. A high Cul7 expression level is detected in the human adult skeletal muscle, placenta, and fetal kidney [6]. Original studies have found that Cul7 is closely related to growth and development. The mutations of Cul7, obscurinlike protein 1 (OBSL1), or coiled-coil domain-containing protein 8 (CCDC8) cause 3-M dwarf syndrome, a primordial growth disorder characterized by developmental retardation before and after birth [10-13]. Cul7 plays an impor- tant role in the development of human and mouse embryos. The homozygote Cul7 gene knockout (Cul7-/-) in mice and human genetic disease models led to developmental defects in the placenta, slow fetus development, late pregnancy, and respiratory failure at birth $[12,14]$. As the core scaffold protein of the Cullin-RING E3 ligase complex [15-18], Cul7 plays an important role in the cell transformation, cycle regulation, senescence, and apoptosis with its ubiquitin ligase activity [19-22]. E3 ubiquitin ligases play a key role in the recognition of target proteins $[23,24]$. Cullin-RING E3 ligase regulates many important biological processes including cell cycle progression, DNA repair, signal transduction, autophagy, and apoptosis [25-30]. Abnormalities in ubiquitin-mediated protein degradation are closely related to tumorigenesis $[16,24,30]$. In recent years, Cul7 has been found highly expressed in tumors and associated with a poor prognosis and malignant development. Bortezomib, a proteasome inhibitor, has been used to treat multiple myeloma and lymphoma. The clinical trials of Bortezomib in the treatment of other malignancies are underway [32-38]. There- 
fore, it may be possible to treat tumors by using Bortezomib to inhibit the high expression of the Cul7-containing E3 ubiquitin ligase complex in tumors. Here, we focus on the relationship between Cul7 and tumors and other biological functions.

Cul7 is abnormally expressed in tumors. In many tumor tissues, Cul7 has been found abnormally expressed [38] and distributed in the nucleus and cytoplasm of cancer cells, with a higher level in the nucleus than in the cytoplasm [39, 40]. The expression level of Cul7 is increasing along with the tumor prognosis and stages. The latest cancer statistics have shown that lung cancer has the highest mortality rate in the world [41]. Using in silico microarray analysis, Cul7 is highly expressed in the nucleus of non-small cell lung cancer, which is positively correlated with the poor prognosis [42, 43]. Primary hepatocellular carcinoma (HCC) is a common malignant tumor. A large number of epidemiological studies have found that metabolic syndromes, including liver fibrosis and cirrhosis caused by non-alcoholic fatty liver disease, are associated with HCC occurrence. Cul7 is reportedly associated with HCC and metabolic syndrome upon the analysis of 20 patients by genomic hybridization [44]. The site of abnormal chromosomal amplification in HCC patients is 6p21.1 on chromosome 6, which is the site of the Cul7 gene. Cul7 is significantly overexpressed in HCC tissues. Immunohistochemical analysis has revealed that 11 of 20 HCC tissues are with high Cul7 expression in the nucleus, while PARC shows no significant changes [44]. Cul7 is highly expressed in the nucleus in the metastatic HCC tissues, which is positively correlated with the poor HCC prognosis [45]. Another study has shown that $\mathrm{Cul} 7$ is with $69.1 \%$ of the positive rate in 162 HCC tissues, but only $29 \%$ of the positive rate in the corresponding adjacent tissues. The abnormal expression of Cul7 is significantly correlated with lymph node metastasis, portal vein tumor thrombosis, and advanced clinical stages. Abnormal Cul7 expression promotes the proliferation, migration, and invasion of HepG2 cells [46]. Cul7 is also highly expressed in the nucleus of breast cancer tissues and significantly correlated with the pathological stage of breast cancer $(\mathrm{p}=0.013)$ and lymph node metastasis $(\mathrm{p}=0.022)$, but negatively correlated with patient prognosis [47]. In epithelial ovarian cancer, the Cul7 expression level is significantly higher in the epithelial ovarian cancer than that in the control tissues, indicating that the Cul7 expression is closely related to the clinical stages, lymph node metastasis, and poor prognosis [48]. Hematopoietic stem cell kinase 1 (HPK1) is expressed in normal pancreatic ducts, but absent in $>95 \%$ of pancreatic cancer, which is rapidly degraded through the Cul7-Fbxw8 ubiquitin ligase complex in the ubiquitin-proteasome pathway [49]. The culmination of studies highlights the abnormally high expression of Cul7 in tumors, which correlates with the pathological stage, metastasis, and prognosis. On the other hand, the downregulation of Cul7 by miR-3940-5p suppresses developments of gliomas [50]. The association of Cul7 and tumors is summarized in Table 1. Therefore, Cul7 is an important clinical tumor marker, which is with the significance to explore the regulatory mechanisms of Cul7 in tumors.

\section{Materials and methods}

Cul7 interacts with tumor-related proteins. The molecular mechanisms of Cul7-associated tumorigenesis have been reported. As an oncogene [42], Cul7 is highly expressed in

Table1. Association of Cul7 with malignant tumors.

\begin{tabular}{|c|c|c|c|c|}
\hline Tumor & Method & Cul7 expression & Regulatory mechanism & References \\
\hline Breast cancer & WB, IHC & $\begin{array}{l}\text { No or weak Cul7 expression in } 26 \text { normal tissues } \\
\text { and Cul7 expression in the nucleus of } 39 \text { breast } \\
\text { cancer tissues. }\end{array}$ & $\begin{array}{l}\text { Cul7 promotes the proliferation and invasion } \\
\text { of breast cancer cells by down-regulating the } \\
\text { expression of p } 53 \text {. }\end{array}$ & [89] \\
\hline Lung cancer & $\mathrm{IHC}$ & $\begin{array}{l}\text { No or weak expression of Cul7 in the cytoplasm } \\
\text { of normal lung mucosa and epithelial cells. } \\
\text { Cul7 is expressed in lung cancer tissues, with a } \\
\text { stronger expression in the nucleus than that in } \\
\text { the cytoplasm. }\end{array}$ & $\begin{array}{l}\text { Cul7 promotes the proliferation and invasion } \\
\text { of lung cancer cells by down-regulating p } 53 \text {. }\end{array}$ & {$[42,43]$} \\
\hline $\mathrm{HCC}$ & qRT-PCR & $\begin{array}{l}\text { Cul7 is expressed in } 91 \% \text { of } 34 \text { HCC tissues, } \\
\text { which is significantly higher than that in adjacent } \\
\text { normal tissues. }\end{array}$ & $\begin{array}{l}\text { Cul7 up-regulates N-cadherin and Vimen- } \\
\text { tin and down-regulates E-cadherin and } \\
\text { a-cadherin promoting EMT transformation } \\
\text { of cells. }\end{array}$ & {$[45]$} \\
\hline $\mathrm{HCC} / \mathrm{MS}$ & IHC & $\begin{array}{l}\text { Cul7 overexpression in } 11 \text { of } 20 \text { HCC patients } \\
\text { with metabolic syndrome. }\end{array}$ & $\begin{array}{l}\text { Cul7 promotes cell proliferation and reduces } \\
\text { apoptosis by targeting the degradation of } \\
\text { Cyclin D1. }\end{array}$ & {$[90]$} \\
\hline $\begin{array}{l}\text { Epithelial ovarian } \\
\text { cancer }\end{array}$ & qRT-PCR & $\begin{array}{l}\text { The positive expression rate of Cul7 in ovarian } \\
\text { cancer tissues is } 2.1-8.4 \text { times higher than that in } \\
\text { normal ovarian epithelial tissues. }\end{array}$ & $\begin{array}{l}\text { Downregulation of Cul7 inhibits the migra- } \\
\text { tion and invasion of cancer cells. }\end{array}$ & {$[48]$} \\
\hline Glioma & $\begin{array}{l}\text { TCGA, CGGA, } \\
\text { WB, IHC }\end{array}$ & $\begin{array}{l}\text { Cul7 is highly expressed in gliomas with high } \\
\text { grade and poor prognosis. }\end{array}$ & $\begin{array}{l}\text { Cul7 is associated and ubiquitin-mediated } \\
\text { MST1 degradation, which promotes the NF- } \\
\kappa \mathrm{B} \text { signaling pathway for glioma development. }\end{array}$ & {$[50]$} \\
\hline
\end{tabular}

Abbreviations: WB-Western blots; IHC-Immunohistochemistry; HCC-Hepatocellular carcinoma; HCC with metabolic syndrome; TCGA-the Cancer Genome Atlas database; CGGA-the Chinese Glioma Genome Atlas database; MST1-mammalian sterile 20 like kinase 1; NF- $\mathrm{B}$-nuclear factor- $\kappa \mathrm{B}$ 


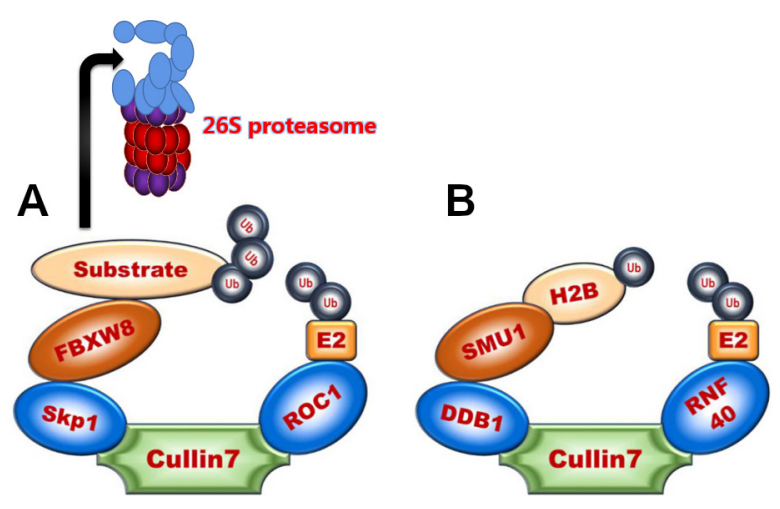

Figure 1. Cullin7 acts as a scaffold protein. A) Cul7 interacts with ROC1 and SKp1-Fbxw8 complex to form the SCF E3 ubiquitin ligase complexes, permitting the degradation of protein substrates; B) Cul7 forms a HECTtype E3 ligase complex with SMU1-DDB1 complex and RNF40 regulating the monoubiquitination of $\mathrm{H} 2 \mathrm{~B}$.

Table 2. Substrates of Cul7 assembled SCF-ROC1-like E3 ubiquitin ligase complex.

\begin{tabular}{lll}
\hline Subtract & Function & Reference \\
\hline Cyclin D1 & $\begin{array}{l}\text { A cellular proto-oncogene, as allosteric } \\
\text { regulators of cyclin-dependent kinase 4 } \\
\text { (CDK4) and CDK6 to regulate cell cycle }\end{array}$ & {$[22,44,54,55]$} \\
& transition from G1 to S phase & \\
& A signaling adaptor to promotes tumor & {$[22,56,57]$} \\
IRS-1 & $\begin{array}{l}\text { growth } \\
\text { A critical negative regulator in the activa- }\end{array}$ & {$[49,58]$} \\
HPK1 & tion of T lymphocytes and dendritic cells & \\
& A marker of malignant cancer cells for & {$[59,60]$} \\
GRASP65 & the ability of cancer cells to invade the & \\
& extracellular matrix & \\
rEga1 & $\begin{array}{l}\text { Eag1 (Kv10.1) potassium (K+) channels } \\
\text { associated with congenital neurodevelop- }\end{array}$ & {$[9,10,61]$} \\
& mental anomalies and tumorigenesis & \\
& An oncogene to stimulate the intrinsic \\
TBC1D3 & GTPase activity of RAB5A, an essential & \\
& actor in early endosome trafficking
\end{tabular}

Abbreviations: IRS-1-insulin receptor substrate 1; HPK1-hematopoietic progenitor kinase 1; GRASP65-Golgi peripheral membrane protein p65; rEga1-rat ether à go-go 1; TBC1D3-Tre-2/Bub2/Cdc16 (TBC1) domain family member 3

different types of tumors [51]. Cul7 promotes tumorigenesis through complex signaling pathways $[1,52]$. Cul7 contains unique domains including $\mathrm{CH}, \mathrm{CPH}, \mathrm{DOC}$, and $\mathrm{BH} 3$, and interacts with the complex of ROC1 and SKp1-Fbxw8 through the $\mathrm{CH}$ domain to form the SCF class of E3 ubiquitin ligase complex [5, 14, 19, 37, 53]. The Cul7 assembled SCF-ROC1like E3 ubiquitin ligase complex permits the degradation of protein substrates (Figure 1A), including cyclin D1 that is a cellular proto-oncogene $[22,44,54,55]$, insulin receptor substrate 1 (IRS-1) that supports tumor growth [22, 56, 57], HPK1 that is a critical negative regulator in the activation of $\mathrm{T}$ lymphocytes and dendritic cells $[49,58]$, Golgi peripheral membrane protein p65 (GRASP65) that is associated with tumor growth and cell apoptosis $[59,60]$, rat ether à go-go 1 (rEgal) that is associated with tumorigenesis $[9,10,61]$, and Tre-2/Bub2/Cdc16 (TBC1) domain family member 3 (TBC1D3) that is an oncogene [62-64] (Table 2). Cul7, as a core scaffold protein, assembles a novel HECT-type E3 ligase complex with suppressor of mec-8 and unc-52 homolog (SMU1), damage-specific DNA Binding Protein 1 (DDB1), and ring finger protein 40 (RNF40), which regulates the monoubiquitination of $\mathrm{H} 2 \mathrm{~B}$ (Figure $1 \mathrm{~B}$ ), thereby affecting cell mitosis and genome stability [65]. An array assay has identified Cul7 binding partners, including p53 [66], SV40 large T antigen [67], Cul9 (PARC) [68], obscurin-like protein 1 (OBSL1), coiled-coil domain containing 8 (CCDC8) [69], DDB 1, and RNF40 [65]. Mutations and/or abnormal expression have shown that these proteins are often associated with tumor development.

Cul7 inhibits apoptosis and promotes cell growth. As an anti-apoptotic oncogene [42], Cul7 promotes cell proliferation by antagonizing p53 functions [66, 69]. p53, as a tumor suppressor protein, is regulated its stability, translation, localization, and transcriptional activity through the extensive post-translational modifications (PTMs) [70-72]. Nuclear magnetic resonance (NMR) spectroscopy has shown that p53 directly binds to the conserved $\mathrm{CPH}$ domain of Cul7, which inhibits p53 transcriptional activity [53, 73, 74]. Mutations in the $\mathrm{CPH}$ domain of $\mathrm{Cul} 7$ inhibit the binding of Cul7 to p53, leading to a recovery of p53 activity. To date, there has been no direct evidence that Cul7 E3 ubiquitin ligase could degrade p53 through polyubiquitination [66, 75]. In the cytoplasm, Cul7 binds directly to p53 to inhibit p53 transcriptional activity, although another E3 ligase, mouse double minute 2 (MDM2) promotes cell survival, proliferation, invasion, and therapeutic resistance by binding to p53 to promotes its degradation through ubiquitination $[66,76]$. However, the Cul7-p53 interaction is cell line dependent [21]. The accumulation of p53 does not occur in either Cul7-suppressed or Cul7-knockout in mouse embryonic fibroblasts (MEFs) [42], but p53 is upregulated in SHEP neuroblastoma cells [21]. In breast cancer and lung cancer cells, the silencing of Cul7 by RNAi increases the p53 expression [77]. The experimental evidence is lacking whether the degradation of Cul7 is induced through the direct polyubiquitination of $\mathrm{p} 53$. Therefore, the specific reasons for Cul7 degradation remain unclear. The overexpression of Cul7 inhibits C-Myc and N-Myc-induced apoptosis of neuroblastoma SHEP cells in a p53-dependent manner [42]. During etoposide-induced DNA damage, the increase in the Cul7 mRNA expression inhibits apoptosis in a p53-dependent manner $[42,66,78,79]$. However, the overexpression of Cul7 promotes apoptosis of NIH3T3 cells through the effect of Cul7 on the integrity of the $\mathrm{BH} 3$ domain. The transfection of mutant Cul7 (1152 stop) in human osteosarcoma U2OS cells reduces the apoptosis induced by MG-132 and etoposides [79]. 


\section{Results}

The overexpression of $\mathrm{Cul} 7$ in the breast cancer cell line HCC1937 enhances cell proliferation, migration, and invasion, but decreases the expression of $\mathrm{p} 53$ and downstream p21 and p27 [46]. In contrast, Cul7 knockdown in BT474 cells inhibits proliferation, migration, and invasion [47]. Cul7 also promotes the proliferation, migration, and invasion of lung cancer cells [43]. When Cul7 is silenced, the expression of p53 and downstream p27 and p21 is increased [43]. Cyclin D1 regulates G1 to S phase of the cell cycle by PTMs. Fbxw8 mediates the ubiquitination of Cyclin D1 through the MAPK kinase-mediated phosphorylation of Thr286 [80]. The conversion of Thr286 to Ala286 or Fbxw8/ Cul1/Cul7 silence stabilizes Cyclin D1 and inhibits the cell cycle progression [80-82]. Cul7 degrades Cyclin D1 in HCC cell lines, HepG2 and SKHep-1, which may contribute to the effect of Cul7 on hepatocarcinogenesis and hepatic metabolic syndrome [44]. In Hela and MDA-MB-231 cells, Cul7 inhibits apoptosis induced by tumor necrosis factor-related apoptosis-inducing ligand (TRAIL) through the ubiquitination of Caspase 8 [51]. Whether Cul7 is an anti- or pro-apoptotic factor requires further clarification in a range of cellular systems. The consensus to-date is that Cul7 inhibits apoptosis, promotes proliferation, and regulates tumor development.

Cul7 contributes to genome stability. DNA damage repair is key to the maintenance of genome stability. Cul7, OBSL1, CCDC8 and Fbxw8 constitute the 3M complex and mutations in these genes are the main cause of $3 \mathrm{M}$ and other growth retardation syndromes [69]. OBSL1 regulates the transcriptional expression of Cul7, while CCDC8 affects the centrosome localization of Cul7. Cul7 and/or OBSL1 silencing results in abnormal microtubule dynamics. In lung cancer NCI-H1155 cells treated with low dose paclitaxel/taxol $(10 \mathrm{nM})$, an anti-tumor agent that stabilizes microtubules, both Cul7 and OBSL1 depletion greatly delayed chromosome alignment and increased the transit time between prometaphase and metaphase. Therefore, the deletion of Cul7 leads to disorders in mitosis and cytokinesis through microtubule defects [69]. Cul9 is a tumor suppressor that is downstream of the $3 \mathrm{M}$ complex and highly homologous to Cul7 regarding Cul9 structure and ability to bind to p53. When Cul9 is silenced, the microtubule dynamics and mitotic disorders caused by the knockdown of Cul7 and OBSL1 can be reversed. Survivin is the strongest apoptotic suppressor gene discovered to date. Cul9 ubiquitinates and degrades Survivin, which is reversed by Cul7 [68]. Cul7 silencing reduces Survivin expression. The exogenous overexpression of Survivin reverses the impairment in microtubule dynamics and mitotic dysfunction caused inhibition. In addition, the deletion of Cul7 in the newly discovered CRL7 $7^{\text {SMU1 }}$ complex leads to chromosomal lagging, the formation of anaphase/ nuclear bridges and multipolar spindles, affecting mitotic processes and genome stability [65]. Based on these results, Cul7 plays an important role in microtubule maintenance, mitosis, and genomic integrity, in addition to tumorigenesis and development. However, the specific mechanism(s) of these effects require further exploration.

Cul7 promotes tumor metastasis. Metastasis is an important characteristic of malignant tumors, which reduces the anticancer therapeutic efficiency and promotes cancerrelated death. The expression of Cul7 is closely related to tumor metastasis. Scratch and invasion assays have shown that the Cul7 silencing inhibits the invasion and migration of choriocarcinoma, ovarian cancer, liver cancer, breast cancer, glioma, and other cancer cell lines, while the Cul7 overexpression promotes cancer cell invasion and migration [50]. Cul7 induces epithelial-mesenchymal transition (EMT), an important mechanism of tumor metastasis and progression, in choriocarcinoma JEG3 cells $[83,84]$. The overexpression of Cul7 increases the expression of zinc finger E-box binding homeobox 1 (ZEB1) and Slug, inhibits the expression of E-cadherin, and enhances the migration and invasion of cancer cells. Cul7 also promotes the invasion and migration of HCC cells through inducing EMT [45]. The expression of Cul7 in HCC cell lines, HCCLM3, SUN886, and SNU423, is stronger than that in non-invasive cell lines, HepG2 and Huh7. The Cul7 silencing in SUN886 cells increases the expression of E-cadherin and catenin but decreases the expression of $\mathrm{N}$-cadherin and Vimentin. The overexpression of Cul7 in HepG2 cells leads to the reverse phenotype. Cul7 promotes the invasion of breast cancer cells through the inhibition of p53. The Cul7 silencing inhibits the invasion and migration of BT474 breast cancer cells, while the downregulation of p53 simultaneously reverses these effects [47]. Therefore, Cul7 promotes tumor invasion and metastasis, but the specific pathways that regulate its ability to ubiquitinate and degrade new substrates require further investigation.

\section{Discussion}

Cul7 is involved in cell senescence. Insulin receptor substrate-1 (IRS-1) mediates the signal transduction through its ability to bind insulin receptors and insulin-like growth factor-1 (IGF-1) receptors, which regulate the glucose metabolism for growth and development. The degradation of IRS-1 is dependent on Cul7 ubiquitin ligase [53, 85]. Following the receptor activation, IRS- 1 is phosphorylated on an array of tyrosine residues and recruited by Src homology 2 (SH2) adaptor proteins to activate downstream Akt and RAS/MEK/ ERK pathways through PI3K and Grb2/SOS, respectively. The inactivation or deletion of Fbxw8 and Cul7 promotes the accumulation of IRS-1 [85, 86]. Cul7 E3 ligase mediates IRS-1 degradation in an mTOR-dependent manner, suggesting that Cul7 is an important regulator of the negative feedback loop of mTOR/IRS- 1 and stably regulates the activity of PI3K and other continuously activated mTOR/S6K targets $[21,87]$. The accumulation of IRS-1 and the persistent activation of Akt, MEK/ERK, and downstream IRS-1 pathways are observed in Cul7-/- MEFs [22]. Although these mitogenic signaling 
pathways are activated, Cul7-/-mice fibroblasts grow slowly and the number of cells arrested in the G1 phase increases. In addition, Cul7-/- fibroblasts exhibit the characteristics of the cell senescence, including the upregulation of the tumor suppressor p16, the low phosphorylation level of $\mathrm{pRb}$, and the increased level of $\beta$-galactosidase [44]. SV40 large T-antigen binds to a 1391-1698 amino acid stretch at the C-terminal of Cul7, which inhibits Cul7 ubiquitination-mediated degradation of IRS-1, enhancing IRS-1 signaling [88].

In summary, Cul7 is highly expressed in multiple malignant tumors, including lung cancer, liver cancer, breast cancer, ovarian cancer, and the expression of Cul7 closely correlates with the clinical staging and prognosis $[43,45,47$, 48]. Cul7 inhibits the activity of apoptotic proteins, promotes the invasion and metastasis of cancer cells, maintains the microtubule and genome stability, and degrades IRS-1 through mTOR to participate in the cell senescence. However, the mechanisms that regulate Cul7 during tumorigenesis are still not fully understood. Cul7 is expressed in the cytoplasm of many non-cancerous tissues, while the immunohistochemistry suggests that Cul7 is overexpressed in the nucleus of tumor cells. The biological role of Cul7 in the nucleus remains unclear. Whether Cul7 could degrade p53 through ubiquitination is also controversial. Cul7 silencing increases the sensitivity of cancer cells to paclitaxel drugs, however, the specific mechanisms of this effect require further investigation. Revealing the in-depth molecular mechanisms of Cul7 in cancer therapy may open new avenues for tumor diagnosis, prognosis, and molecular targeted therapy.

Acknowledgments: This work was supported by the Youth scientific research foundation of the Affiliated Hospital of Hebei University (grant numbers 2017Q002), the National Natural Science Foundation of China (grant numbers 81560483), and the Hebei province government foundation for clinical medical talents training and basic research projects (grant numbers 361007).

\section{References}

[1] KITAGAWA K, KITAGAWA M. The SCF-type E3 Ubiquitin Ligases as Cancer Targets. Curr Cancer Drug Targets 2016; 16: 119-129. https://doi.org/10.2174/1568009616666151112 122231

[2] NOMURA N, NAGASE T, MIYAJIMA N, SAZUKA T, TANAKA A et al. Prediction of the coding sequences of unidentified human genes. II. The coding sequences of 40 new genes (KIAA0041-KIAA0080) deduced by analysis of cDNA clones from human cell line KG-1. DNA Res 1994; 1: 223229. https://doi.org/10.1093/dnares/1.5.223

[3] SARIKAS A, HARTMANN T, PAN ZQ. The cullin protein family. Genome Biol 2011; 12: 220. https://doi.org/10.1186/ gb-2011-12-4-220

[4] ZHENG N, ZHOU Q, WANG Z, WEI W. Recent advances in SCF ubiquitin ligase complex: Clinical implications. Biochim Biophys Acta 2016; 1866: 12-22. https://doi.org/10.1016/j. bbcan.2016.05.001
[5] ZIMMERMAN ES, SCHULMAN BA, ZHENG N. Structural assembly of cullin-RING ubiquitin ligase complexes. Curr Opin Struct Biol 2010; 20: 714-721. https://doi.org/10.1016/j. sbi.2010.08.010

[6] DIAS DC, DOLIOS G, WANG R, PAN ZQ. CUL7: A DOC domain-containing cullin selectively binds Skp1.Fbx29 to form an SCF-like complex. Proc Natl Acad Sci U S A 2002; 99: 16601-16606. https://doi.org/10.1073/pnas.252646399

[7] GROSSBERGER R, GIEFFERS C, ZACHARIAE W, PODTELEJNIKOV AV, SCHLEIFFER A et al. Characterization of the DOC1/APC10 subunit of the yeast and the human anaphase-promoting complex. J Biol Chem 1999; 274: 1450014507. https://doi.org/10.1074/jbc.274.20.14500

[8] KIPREOS ET, LANDER LE, WING JP, HE WW, HEDGECOCK EM. cul-1 is required for cell cycle exit in C. elegans and identifies a novel gene family. Cell 1996; 85: 829-839. https://doi.org/10.1016/s0092-8674(00)81267-2

[9] KOMINAMI K, SETH-SMITH H, TODA T. Apc10 and Ste9/ Srw1, two regulators of the APC-cyclosome, as well as the CDK inhibitor Rum1 are required for G1 cell-cycle arrest in fission yeast. EMBO J 1998; 17: 5388-5399. https://doi. org/10.1093/emboj/17.18.5388

[10] HUBER C, DIAS-SANTAGATA D, GLASER A O'SULLIVAN J, BRAUNER R et al. Identification of mutations in CUL7 in 3-M syndrome. Nat Genet 2005; 37: 11191124. https://doi.org/10.1038/ng1628

[11] MAKSIMOVA N, HARA K, MIYASHIA A, NIKOLAEVA I, SHIGA A et al. Clinical, molecular and histopathological features of short stature syndrome with novel CUL7 mutation in Yakuts: new population isolate in Asia. J Med Genet 2007; 44: 772-778. https://doi.org/10.1136/jmg.2007.051979

[12] HASEGAWA K, TANAKA H, HIGUCHI Y, YAMASHITA $M$, TSUKAHARA $H$. Changes in facial appearance from neonate to adult in 3-M syndrome patient with novel CUL7 gene mutations. J Pediatr Endocrinol Metab 2016; 29: 241246. https://doi.org/10.1515/jpem-2015-0272

[13] HANSON D, MURRAY PG, COULSON T, SUD A, OMOKANYE A et al. Mutations in CUL7, OBSL1 and CCDC8 in 3-M syndrome lead to disordered growth factor signalling. J Mol Endocrinol 2012; 49: 267-275. https://doi.org/10.1530/ JME-12-0034

[14] ARAI T, KASPER JS, SKAAR JR, ALI SH, TAKAHASHI C et al. Targeted disruption of p185/Cul7 gene results in abnormal vascular morphogenesis. Proc Natl Acad Sci U S A 2003; 100: 9855-9860. https://doi.org/10.1073/pnas.1733908100

[15] BULATOV E, ZAGIDULLIN A, VALIULLINA A, SAYAROVA R, RIZVANOV A. Small Molecule Modulators of RING-Type E3 Ligases: MDM and Cullin Families as Targets. Front Pharmacol 2018; 9: 450. https://doi.org/10.3389/ fphar.2018.00450

[16] LEE J, ZHOU P. Cullins and cancer. Genes Cancer 2010; 1: 690-699. https://doi.org/10.1177/1947601910382899

[17] PETROSKI MD, DESHAIES RJ. Function and regulation of cullin-RING ubiquitin ligases. Nat Rev Mol Cell Biol 2005; 6: 9-20. https://doi.org/10.1038/nrm1547

[18] SOUCY TA, SMITH PG, MILHOLLEN MA, BERGER AJ, GAVIN JM et al. An inhibitor of NEDD8-activating enzyme as a new approach to treat cancer. Nature 2009; 458: 732736. https://doi.org/10.1038/nature07884

[19] ALI SH, KASPER JS, ARAI T, DECAPRIO JA. Cul7/p185/ p193 binding to simian virus 40 large $\mathrm{T}$ antigen has a role in cellular transformation. J Virol 2004; 78: 2749-2757. https:// doi.org/10.1128/jvi.78.6.2749-2757.2004 
[20] LAFONTANT PJ, FIELD LJ. The cardiomyocyte cell cycle. Novartis Found Symp 2006; 274: 196-207; discussion 208213, 272-276. https://doi.org/10.1002/0470029331.ch12

[21] SARIKAS A, XU X, FIELD LJ, PAN ZQ. The cullin7 E3 ubiquitin ligase: a novel player in growth control. Cell Cycle 2008; 7: 3154-3161. https://doi.org/10.4161/cc.7.20.6922

[22] XU X, SARIKAS A, DIAS-SANTAGATA DC, DOLIOS G, LAFONTANT PJ, et al. The CUL7 E3 ubiquitin ligase targets insulin receptor substrate 1 for ubiquitin-dependent degradation. Mol Cell 2008; 30: 403-414. https://doi.org/10.1016/j. molcel.2008.03.009

[23] LYDEARD JR, SCHULMAN BA, HARPER JW. Building and remodelling Cullin-RING E3 ubiquitin ligases. EMBO Rep 2013; 14: 1050-1061. https://doi.org/10.1038/embor. 2013.173

[24] LIU J, SHAIK S, DAI X, WU Q, ZHOU X et al. Targeting the ubiquitin pathway for cancer treatment. Biochim Biophys Acta 2015; 1855: 50-60. https://doi.org/10.1016/j. bbcan.2014.11.005

[25] ABBAS T, DUTTA A. Regulation of Mammalian DNA Replication via the Ubiquitin-Proteasome System. Adv Exp Med Biol 2017; 1042: 421-454. https://doi.org/10.1007/978-98110-6955-0_19

[26] CHEN Z, SUI J, ZHANG F, ZHANG C. Cullin family proteins and tumorigenesis: genetic association and molecular mechanisms. J Cancer 2015; 6: 233-242. https://doi. org/10.7150/jca.11076

[27] CUI D, XIONG X, ZHAO Y. Cullin-RING ligases in regulation of autophagy. Cell Div 2016; 11: 8. https://doi. org/10.1186/s13008-016-0022-5

[28] JANG SM, REDON CE, ALADJEM MI. Chromatin-Bound Cullin-Ring Ligases: Regulatory Roles in DNA Replication and Potential Targeting for Cancer Therapy. Front Mol Biosci 2018; 5: 19. https://doi.org/10.3389/fmolb.2018.00019

[29] VENUTO S, MERLA G. E3 Ubiquitin Ligase TRIM Proteins, Cell Cycle and Mitosis. Cells 2019; 8: 510. https://doi. org/10.3390/cells8050510

[30] ZHAO Y, SUN Y. Cullin-RING Ligases as attractive anti-cancer targets. Curr Pharm Des 2013; 19: 3215-3225. https:// doi.org/10.2174/13816128113199990300

[31] BOCHIS OV, FETICA B, VLAD C, ACHIMAS-CADARIU P, IRIMIE A. The Importance of Ubiquitin E3 Ligases, SCF and APC/C, in Human Cancers. Clujul Med 2015; 88: 9-14. https://doi.org/10.15386/cjmed-377

[32] ADAMS J, BEHNKE M, CHEN S, CRUICKSHANK AA, DICK LR et al. Potent and selective inhibitors of the proteasome: dipeptidyl boronic acids. Bioorg Med Chem Lett 1998; 8: 333-338. https://doi.org/10.1016/s0960-894x(98)00029-8

[33] AGHAJANIAN C, SOIGNET S, DIZON DS, PIEN CS, ADAMS J, et al. A phase I trial of the novel proteasome inhibitor PS341 in advanced solid tumor malignancies. Clin Cancer Res 2002; 8: 2505-2511.

[34] DIMOPOULOS MA, GOLDSCHMIDT H, NIESVIZKY R, JOSHUA D, CHNG WJ et al. ENDEAVOR Investigators. Carfilzomib or bortezomib in relapsed or refractory multiple myeloma (ENDEAVOR): an interim overall survival analysis of an open-label, randomised, phase 3 trial. Lancet Oncol 2017; 18: 1327-1337. https://doi.org/10.1016/S14702045(17)30578-8
[35] KUMAR SK, JETT J, MARKS R, RICHARDSON R, QUEVEDO F, et al. Phase 1 study of sorafenib in combination with bortezomib in patients with advanced malignancies. Invest New Drugs 2013; 31: 1201-1206. https://doi. org/10.1007/s10637-013-0004-2

[36] LI T, HO L, PIPERDI B, ELRAFEI T, CAMACHO FJ et al. Phase II study of the proteasome inhibitor bortezomib (PS341 , Velcade) in chemotherapy-naive patients with advanced stage non-small cell lung cancer (NSCLC). Lung Cancer 2010; 68: 89-93. https://doi.org/10.1016/j.lungcan.2009.05.009

[37] NIKESITCH N, TAO C, LAI K, KILLINGSWORTH M, BAE S et al. Predicting the response of multiple myeloma to the proteasome inhibitor Bortezomib by evaluation of the unfolded protein response. Blood Cancer J 2016; 6: e432. https://doi.org/10.1038/bcj.2016.40

[38] PAPANDREOU CN, LOGOTHETIS CJ. Bortezomib as a potential treatment for prostate cancer. Cancer Res 2004; 64: 5036-5343. https://doi.org/10.1158/0008-5472.CAN-03-2707

[39] SOLNESTAM BW, STRANNEHEIM H, HALLMAN J, KALLER M, LUNDBERG E et al. Comparison of total and cytoplasmic mRNA reveals global regulation by nuclear retention and miRNAs. BMC Genomics 2012; 13: 574. https:// doi.org/10.1186/1471-2164-13-574

[40] BAHAR HALPERN K, CASPI I, LEMZE D, LEVY M, LANDEN S, et al. Nuclear Retention of mRNA in Mammalian Tissues. Cell Rep 2015; 13: 2653-2662. https://doi. org/10.1016/j.celrep.2015.11.036

[41] SIEGEL RL, MILLER KD, JEMAL A. Cancer statistics, 2019. CA Cancer J Clin 2019; 69: 7-34. https://doi.org/10.3322/ caac. 21551

[42] KIM SS, SHAGO M, KAUSTOV L, BOUTROS PC, CLENDENING JW et al. CUL7 is a novel antiapoptotic oncogene. Cancer Res 2007; 67: 9616-9622. https://doi. org/10.1158/0008-5472.CAN-07-0644

[43] MEN X, WANG L, YU W, JU Y. Cullin7 is required for lung cancer cell proliferation and is overexpressed in lung cancer. Oncol Res 2015; 22: 123-128. https://doi.org/10.3727/09650 4014X14198596979742

[44] PARADIS V, ALBUQUERQUE M, MEBARKI M, HERNANDEZ L, ZALINSKI S et al. Cullin7: a new gene involved in liver carcinogenesis related to metabolic syndrome. Gut 2013; 62: 911-919. https://doi.org/10.1136/gutjnl-2012-302091

[45] ZHANG D, YANG G, LI X, XU C, GE H. Inhibition of Liver Carcinoma Cell Invasion and Metastasis by Knockdown of Cullin7 In Vitro and In Vivo. Oncol Res 2016; 23: 171-181. https://doi.org/10.3727/096504016X14519995067562

[46] AN J, ZHANG Z, LIU Z, WANG R, HUI D et al. Overexpression of Cullin7 is associated with hepatocellular carcinoma progression and pathogenesis. BMC Cancer 2017; 17: 828. https://doi.org/10.1186/s12885-017-3839-7

[47] GUO H, WU F, WANG Y, YAN C, SU W. Overexpressed ubiquitin ligase Cullin7 in breast cancer promotes cell proliferation and invasion via down-regulating p53. Biochem Biophys Res Commun 2014; 450: 1370-1376. https://doi. org/10.1016/j.bbrc.2014.06.134

[48] XI J, ZENG ST, GUO L, FENG J. High Expression of Cullin7 Correlates with Unfavorable Prognosis in Epithelial Ovarian Cancer Patients. Cancer Invest 2016; 34: 130-136. https:// doi.org/10.3109/07357907.2015.1114123 
[49] WANG H, CHEN Y, LIN P, LI L, ZHOU G et al. The CUL7/ F-box and WD repeat domain containing 8 (CUL7/Fbxw8) ubiquitin ligase promotes degradation of hematopoietic progenitor kinase 1. J Biol Chem 2014; 289: 4009-4017. https:// doi.org/10.1074/jbc.M113.520106

[50] XU J, ZHANG Z, QIAN M, WANG S, QIU W et al. Cullin-7 (CUL7) is overexpressed in glioma cells and promotes tumorigenesis via NF-kappaB activation. J Exp Clin Cancer Res 2020; 39: 59. https://doi.org/10.1186/s13046-020-01553-7

[51] KONG Y, WANG Z, HUANG M, ZHOU Z, LI Y et al. CUL7 promotes cancer cell survival through promoting Caspase-8 ubiquitination. Int J Cancer 2019; 145: 1371-1381. https:// doi.org/10.1002/ijc.32239

[52] CHEN P, YAO GD. The role of cullin proteins in gastric cancer. Tumour Biol 2016; 37: 29-37. https://doi.org/10.1007/ s13277-015-4154-z

[53] KAUSTOV L, LUKIN J, LEMAK A, DUAN S, HO M et al. The conserved $\mathrm{CPH}$ domains of $\mathrm{Cul7}$ and PARC are proteinprotein interaction modules that bind the tetramerization domain of p53. J Biol Chem 2007; 282: 11300-11307. https:// doi.org/10.1074/jbc.M611297200

[54] QIE S, DIEHL JA. Cyclin D1, cancer progression, and opportunities in cancer treatment. J Mol Med (Berl) 2016; 94: 1313-1326. https://doi.org/10.1007/s00109-016-1475-3

[55] BATES S, PETERS G. Cyclin D1 as a cellular proto-oncogene. Semin Cancer Biol 1995; 6: 73-82. https://doi.org/10.1006/ scbi.1995.0010

[56] REISS K, DEL VALLE L, LASSAK A, TROJANEK J. Nuclear IRS-1 and cancer. J Cell Physiol 2012; 227: 2992-3000. https://doi.org/10.1002/jcp.24019

[57] METZ HE, KARGL J, BUSCH SE, KIM KH, KURLAND BF, et al. Insulin receptor substrate-1 deficiency drives a proinflammatory phenotype in KRAS mutant lung adenocarcinoma. Proc Natl Acad Sci U S A 2016; 113: 8795-8800. https:// doi.org/10.1073/pnas.1601989113

[58] LIU J, CURTIN J, YOU D, HILLERMAN S, LI-WANG B et al. Critical role of kinase activity of hematopoietic progenitor kinase 1 in anti-tumor immune surveillance. PLoS One 2019; 14: e0212670. https://doi.org/10.1371/journal.pone.0212670

[59] WANG F, CHEN X, YUAN D, YI Y, LUO Y. Golgi reassembly and stacking protein 65 downregulation is required for the anti-cancer effect of dihydromyricetin on human ovarian cancer cells. PLoS One 2019; 14: e0225450. https://doi. org/10.1371/journal.pone.0225450

[60] LITTERMAN N, IKEUCHI Y, GALLARDO G, O'CONNELL BC, SOWA ME et al. An OBSL1-Cul7Fbxw8 ubiquitin ligase signaling mechanism regulates Golgi morphology and dendrite patterning. PLoS Biol 2011; 9: e1001060. https://doi. org/10.1371/journal.pbio. 1001060

[61] AYALA I, CRISPINO R, COLANZI A. GRASP65 controls Golgi position and structure during G2/M transition by regulating the stability of microtubules. Traffic 2019; 20: 785-802. https://doi.org/10.1111/tra.12682

[62] WANG B, ZHAO H, ZHAO L, ZHANG Y, WAN Q et al. Up-regulation of OLR1 expression by TBC1D3 through activation of TNFalpha/NF-kappaB pathway promotes the migration of human breast cancer cells. Cancer Lett 2017; 408: 60-70. https://doi.org/10.1016/j.canlet.2017.08.021
[63] KONG C, LANGE JJ, SAMOVSKI D, SU X, LIU J et al. Ubiquitination and degradation of the hominoid-specific oncoprotein TBC1D3 is regulated by protein palmitoylation. Biochem Biophys Res Commun 2013; 434: 388-393. https://doi. org/10.1016/j.bbrc.2013.04.001

[64] HODZIC D, KONG C, WAINSZELBAUM MJ, CHARRON AJ, SU X et al. TBC1D3, a hominoid oncoprotein, is encoded by a cluster of paralogues located on chromosome $17 \mathrm{q} 12$. Genomics 2006; 88: 731-736. https://doi.org/10.1016/j.ygeno.2006.05.009

[65] SHAH VJ, MADDIKA S. CRL7(SMU1) E3 ligase complexdriven $\mathrm{H} 2 \mathrm{~B}$ ubiquitylation functions in sister chromatid cohesion by regulating SMC1 expression. J Cell Sci 2018; 131: jcs213868. https://doi.org/10.1242/jcs.213868

[66] ANDREWS P, HE YJ, XIONG Y. Cytoplasmic localized ubiquitin ligase cullin 7 binds to $\mathrm{p} 53$ and promotes cell growth by antagonizing p53 function. Oncogene 2006; 25: 4534-4548. https://doi.org/10.1038/sj.onc. 1209490

[67] KASPER JS, KUWABARA H, ARAI T, ALI SH, DECAPRIO JA. Simian virus 40 large $T$ antigen's association with the CUL7 SCF complex contributes to cellular transformation. J Virol 2005; 79: 11685-11692. https://doi.org/10.1128/ JVI.79.18.11685-11692.2005

[68] LI Z, PEI XH, YAN J, YAN F, CAPPELL KM et al. CUL9 mediates the functions of the $3 \mathrm{M}$ complex and ubiquitylates survivin to maintain genome integrity. Mol Cell 2014; 54: 805-819. https://doi.org/10.1016/j.molcel.2014.03.046

[69] YAN J, YAN F, LI Z, SINNOTT B, CAPPELL KM et al. The $3 \mathrm{M}$ complex maintains microtubule and genome integrity. Mol Cell 2014; 54: 791-804. https://doi.org/10.1016/j.molcel.2014.03.047

[70] MEEK DW, ANDERSON CW. Posttranslational modification of p53: cooperative integrators of function. Cold Spring Harb Perspect Biol 2009; 1: a000950. https://doi.org/10.1101/ cshperspect.a000950

[71] KRUSE JP, GU W. Modes of p53 regulation. Cell 2009; 137: 609-622. https://doi.org/10.1016/j.cell.2009.04.050

[72] DEHART CJ, CHAHAL JS, FLINT SJ, PERLMAN DH. Extensive post-translational modification of active and inactivated forms of endogenous p53. Mol Cell Proteomics 2014; 13: 1-17. https://doi.org/10.1074/mcp.M113.030254

[73] NOMURA K, KLEJNOT M, KOWALCZYK D, HOCK AK, SIBBET GJ, et al. Structural analysis of MDM2 RING separates degradation from regulation of $\mathrm{p} 53$ transcription activity. Nat Struct Mol Biol 2017; 24: 578-587. https://doi. org/10.1038/nsmb.3414

[74] HOCK AK, VOUSDEN KH. The role of ubiquitin modification in the regulation of p53. Biochim Biophys Acta 2014; 1843: 137-149. https://doi.org/10.1016/j.bbamcr.2013.05.022

[75] KASPER JS, ARAI T, DECAPRIO JA. A novel p53-binding domain in CUL7. Biochem Biophys Res Commun 2006; 348: 132-138. https://doi.org/10.1016/j.bbrc.2006.07.013

[76] LI W, PENG X, LANG J, XU C. Targeting Mouse Double Minute 2: Current Concepts in DNA Damage Repair and Therapeutic Approaches in Cancer. Front Pharmacol 2020; 11: 631. https://doi.org/10.3389/fphar.2020.00631 
[77] QIU N, HE Y, ZHANG S, HU X, CHEN M et al. Cullin 7 is a predictor of poor prognosis in breast cancer patients and is involved in the proliferation and invasion of breast cancer cells by regulating the cell cycle and microtubule stability. Oncol Rep 2018; 39: 603-610. https://doi.org/10.3892/ or.2017.6106

[78] JUNG P, VERDOODT B, BAILEY A, YATES JR, 3RD, MENSSEN A et al. Induction of cullin 7 by DNA damage attenuates p53 function. Proc Natl Acad Sci U S A 2007; 104: 11388-11393. https://doi.org/10.1073/pnas.0609467104

[79] DOWELL JD, TSAI SC, DIAS-SANTAGATA DC, NAKAJIMA H, WANG Z et al. Expression of a mutant p193/ CUL7 molecule confers resistance to MG132- and etoposide-induced apoptosis independent of p53 or Parc binding. Biochim Biophys Acta 2007; 1773: 358-366. https://doi. org/10.1016/j.bbamcr.2006.11.020

[80] OKABE H, LEE SH, PHUCHAREON J, ALBERTSON DG, MCCORMICK F et al. A critical role for FBXW8 and MAPK in cyclin D1 degradation and cancer cell proliferation. PLoS One 2006; 1: e128. https://doi.org/10.1371/journal. pone. 0000128

[81] TSUNEMATSU R, NISHIYAMA M, KOTOSHIBA S, SAIGA T, KAMURA T et al. Fbxw8 is essential for Cul1-Cul7 complex formation and for placental development. Mol Cell Biol 2006; 26: 6157-6169. https://doi.org/10.1128/MCB.00595-06

[82] PONYEAM W, HAGEN T. Characterization of the Cullin7 E3 ubiquitin ligase--heterodimerization of cullin substrate receptors as a novel mechanism to regulate cullin E3 ligase activity. Cell Signal 2012; 24: 290-295. https://doi. org/10.1016/j.cellsig.2011.08.020

[83] FU J, LV X, LIN H, WU L, WANG R et al. Ubiquitin ligase cullin 7 induces epithelial-mesenchymal transition in human choriocarcinoma cells. J Biol Chem 2010; 285: 10870-10879. https://doi.org/10.1074/jbc.M109.004200
[84] CHAFFER CL, SAN JUAN BP, LIM E, WEINBERG RA. EMT, cell plasticity and metastasis. Cancer Metastasis Rev 2016; 35: 645-654. https://doi.org/10.1007/s10555-0169648-7

[85] XU X, KESHWANI M, MEYER K, SARIKAS A, TAYLOR $S$ et al. Identification of the degradation determinants of insulin receptor substrate 1 for signaling cullin-RING E3 ubiquitin ligase 7-mediated ubiquitination. J Biol Chem 2012; 287: 40758-40766. https://doi.org/10.1074/jbc. M112.405209

[86] SCHEUFELE F, WOLF B, KRUSE M, HARTMANN T, LEMPART J et al. Evidence for a regulatory role of Cullin-RING E3 ubiquitin ligase 7 in insulin signaling. Cell Signal 2014; 26: 233-239. https://doi.org/10.1016/j.cellsig.2013.11.005

[87] DESTEFANO MA, JACINTO E. Regulation of insulin receptor substrate-1 by mTORC2 (mammalian target of rapamycin complex 2). Biochem Soc Trans 2013; 41: 896-901. https://doi.org/10.1042/BST20130018

[88] HARTMANN T, XU X, KRONAST M, MUEHLICH S, MEYER K, et al. Inhibition of Cullin-RING E3 ubiquitin ligase 7 by simian virus 40 large T antigen. Proc Natl Acad Sci U S A 2014; 111: 3371-3376. https://doi.org/10.1073/ pnas. 1401556111

[89] GUO H, WU F, WANG Y, YAN C, SU W. Overexpressed ubiquitin ligase Cullin7 in breast cancer promotes cell proliferation and invasion via down-regulating p53. Biochem Biophys Res Commun 2014; 450: 1370-1376. https://doi. org/10.1016/j.bbrc.2014.06.134

[90] PARADIS V, ALBUQUERQUE M, MEBARKI M, HERNANDEZ L, ZALINSKI S et al. Cullin7: a new gene involved in liver carcinogenesis related to metabolic syndrome. Gut 2013; 62: 911-919. https://doi.org/10.1136/gutjnl-2012-302091 